\title{
Transitivity Networks and Meaning Transmission in Translation
}

Mohamed Mohamed Tohamy

Faculty of Arts \& Humanities

Suez Canal University

mohamed_tohamy@art.suez.edu.eg

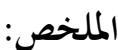

تقوم هذه الدراسة على تحليل التغير الذي يطرأ على علاقات التعدي في الجملة عند ترجمة

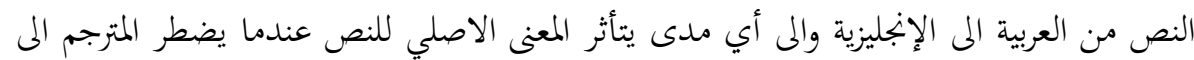

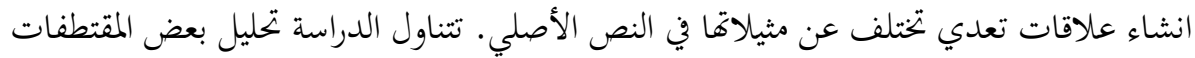
من الترجمة الإنجليزية لكتاب الديمقراطية وحقوق الإنسان والثريعة في الفكر الإسلامي للمفكريك

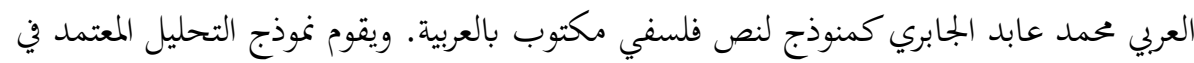
هذه الدراسة على نظرية اللسانيات الوظيفية النسقية كما وضعها هاليداي وتلاميذه. وتستخدم الدراسة علاقات التعدي كأدوت لتحليل الجملة في النص العربي والمترجم وذلك في أطار الوظيفة

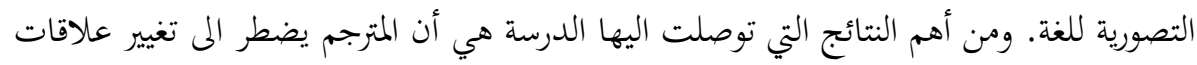

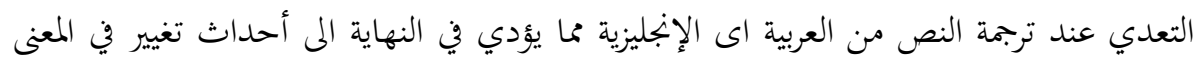

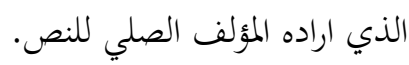
كلمات مفتاحية: الترجمة - نظرية اللسانيات الوظيفية - الوظيفة التصورية للغة - التعدي

$$
\text { - المعني المعرفي - نصوص فلسفية - تحولات الترجمة. }
$$




\section{Abstract:}

This study investigates the extent to which transitivity relations in the source text (ST) are affected by the nature of the target text (TT) language when the ST is translated from one language to another. The study analyses extracts from a translation of the Arab thinker and philosopher Mohamed Abed Al-jabri's (1935-2010) book Democracy, Human Rights and Law in Islamic Thought which was translated by The Centre for Arab Unity Studies. The model of analysis is based on the ideational metafunction which is an important aspect of the Systemic Functional Linguistics theory. The ideational metafunction is adopted as it is the one which realizes cognitive meaning in the form of propositions. Transitivity networks (with their processes and participants) represent the tool of analysis through which the researcher discovers the extent to which the translation of this sophisticated philosophical text from Arabic into English can result in process and participant shifts. The results provide evidence that there are clear shifts, and sometimes contraction/expansion, of processes and participants in the translated text and, consequently, the cognitive meaning undergoes shift and deviation from the author's intended meaning.

Key words: translation - systemic functional linguistics ideational metafunction - transitivity - cognitive meaning philosophical text- translation shift. 


\section{Introduction:}

This study is based on a question that was posed by Bell (1993) regarding the resources that the language "code possess[es] for the transmission ... of particular kinds of meaning" (p. 117). This question handles the process of translation from the perspective of investigating "the functions of language as a system of communication" (p. 117). The study analyzes the differences in transitivity systems between an Islamic philosophical text written in Arabic namely, Mohamed Abed Al-jabri's (1935-2010) book Democracy, Human Rights and Law in Islamic Thought, and its translation into English. The study also identifies the reasons behind the differences in transitivity relations in the two texts. To analyze transitivity, we are concerned with the writer's or the translator's choices from a range of possibilities that yield different types of meanings (Halliday, 1970). Functionalists believe that grammar is a reflection of reality, or of the processes that take place in the real world. Martin et al. (1997, p.100-101) explain that when communicants observe things happening, they turn this experience of observing into meaning. This meaning is construed as a configuration of grammatical structures that reflect their experience of observing something happening. This approach to transitivity "takes into consideration a paradigmatic conception of language in which choice plays a primary function" (Perez, 2007, p. 68). Communicants compose their strings of 
grammatical components after making their choices regarding the world reality they want to communicate.

It is significant to emphasize that Halliday is concerned with discovering meaning potential in authentic writings rather than translations. Hence, it is crucial to "investigate how this notion of meaning potential travels when an original text is translated" (Bosseaux, 2007, p. 50).

\section{Translating philosophical texts}

Whereas translation studies have paid a great deal of attention to issues concerning literary translation, their inclination to investigating issues related to the translation of philosophical texts has been somewhat limited (Foran, 2012, p. 3). Foran (2012, p.13) admits that the translation of philosophical texts has occupied a marginal position in the current translation theory because of what he referred to as the "inherent ambiguity" of philosophical writings. The term "inherent ambiguity" was coined by the Polish philosopher Roman Ingarden (1893- 1970) who distinguishes between three classes of ambiguity: ambiguity that is intended by the author, ambiguity imposed by the author's mode of thinking and accidental ambiguity that is ignored by the author as it may cause minor problems to the reader (Ingarden, 1991). Ambiguity represents a challenge facing the translator who is required to preserve the intended meaning and, at the same 
time, maintain a certain amount of the stylistic features of the original philosophical text.

\section{Theoretical Background}

Bell (1993) suggests a model of translation analysis that is based on three main assumptions. Firstly, he poses that "the grammar of a language is a system of options which are available to the user for the expression of meaning" (P. 120). Secondly, any linguistic structure must contain three types of meaning namely, cognitive (how the meaning of a clause is related to a phenomenon in the real world), speech functional (how language is used as a means of social interaction) and discoursal (how the meaning of a clause is related to other clauses). Thirdly, these types of meaning are recognized by a series of options or networks which are referred to as metafunctions. Although the Systemic Functional Linguistics theory (SFL) is based on three types of metafunctions namely, ideational, interpersonal and textual, this study focuses mainly on the ideational metafunction as it is the one which realizes meaning in the form of propositions (ibid). Transitivity networks, with their processes, participants and circumstances, represent the tools of analysis adopted for this study. Halliday (1967) describes transitivity as "the set of options relating to cognitive context, the linguistic representation of extra linguistic experience, whether of phenomena of the external world, or of feelings, thoughts and perception" (p.199). In the same respect, Simpson (1993) and Perez (2007) relate 
transitivity networks to reality and to the encoding of meaning as mental pictures that account for people's experience in the world. The researcher, thus, finds it appropriate to adopt transitivity networks for analyzing the translation of philosophical discourse as these networks are "concerned with the transmission of ideas" (Simpson, 1993, P. 88).

\subsection{Transitivity}

Halliday (2014) and Eggins (2004) state that transitivity analysis in a clause describes three aspects of meaning: (1) processes that are realized in the verbal group, (2) participants that are realized in the nominal group, and (3) circumstances that are expressed by adverbials or prepositional phrases. Halliday (2014) distinguishes between material, mental, verbal, relational, existential and behavioral clauses. Each type of clause has its own processes, participants and circumstances.

\subsubsection{Material Processes}

Halliday (2014) describes material processes simply as the "processes of doing and happening" (p. 224). The semantic definitions of material processes, according to Eggins (2004) is that "some entity does something, undertakes some action" (p.214). Participants in Material processes include Actor, Goal, Scope and Recipient. The Actor is the constituent that is responsible for doing the action, or according to Halliday (2014) "the source of energy bringing about the change" (p.224). Another participant is the Goal to whom the doing is directed or extended. This is illustrated in examples 1 below: 
1. [Actor] The lion [Pr: Material] caught [Goal] the tourist.

(Halliday, 2014, p.226)

In addition, material clauses can include other participant roles labelled as Scope and Recipient. The scope, known as Range in earlier versions of the theory (Halliday, 1994, P. 146-9; Matthiessen, Teruya, Lam, 2010, p. 170) is different from Goal in that it is "not in any way affected by the performance of the process. Rather, it either construes the domain over which the process takes place $\ldots$ or construes the process itself" (Halliday, 2014, p. 239). In example 2, the clause constituent Hyde Park and the Domain is a Scope as it represents the domain where the process takes place:

2. Then [pr: material] cross [Scope] Hyde Park and the Domain [Circumstance: place] to the Art Gallery of NSW.

(Halliday, 2014, p.236)

As for the Recipient, earlier referred to by Halliday as Beneficiary (Halliday, 1994, P. 220; Matthiessen, Teruya, Lam, 2010, p. 66), it is defined as the participant "benefitting from the performance of the process" (Halliday, 2014, p.237). Recipients can occur with or without a prepositional phrase as in example 3.

3.a [Actor] He [Pr: material] gave [Recipient] John [Goal] the parcel. 
3.b. [Actor] He [Pr: material] gave [Goal] the parcel [Recipient] to John.

\subsubsection{Mental processes}

Mental clauses are concerned with sensing (Simpson, 1993, p. 91) or "our experience of the world of our own consciousness" (Halliday, 2014, p. 245). Halliday classifies the verbs serving as processes in mental clauses as perceptive (see, notice), cognitive (think, believe), desiderative (want, wish), and emotive (like, fear) (p. 257). The participant roles for mental clauses are Senser and Phenomenon. The Senser, the one who feels, thinks, wants, or perceives must be a human participant or an anthropomorphized non-human (Eggins, 2004 , p. 227). The phenomenon is the participant which is thought, felt, perceived, or wanted. Moreover, Halliday identifies two types of phenomena: Acts and Facts. As illustrated in example 4, an Act Phenomenon is recognized as an imperfective non-finite clause acting as a noun:

4. [Senser] I [Pr: Mental] saw [Phenomenon: Act] the operation taking place.

(Eggins, 2004, 227)

As for Fact Phenomenon, it is recognized as an embedded clause introduced by 'that'. In example 5, the bold that-clause is a Fact-Phenomenon functioning as a noun:

5. [Senser] I [Pr: Mental] regret [Circumstance] very much [Phenomenon: Fact] that $I$ was away from home. 
(Halliday, 2014, p.252)

\subsubsection{Relational Processes}

The third major type of processes described by Halliday is "relational processes" or "processes of being and having" (2014, p. 259). Eggins (2004, p.239) differentiates between two types of relational processes namely, intensive attributive processes and intensive identifying processes. However, in his latest version of Transitivity theory, Halliday (2014) refers to three major categories of relational clauses as shown in Table 1:

Table 1: The Principal Categories of relational clause (adapted from: Halliday, 2014, p. 265)

\begin{tabular}{|c|c|c|}
\hline & $\begin{array}{l}\text { (i) } \\
\text { Attributive ' } a \text { is } \\
\text { an attributive of } \\
x \text { ' }\end{array}$ & $\begin{array}{l}\text { (ii) } \\
\text { Identifying ' } a \text { is } \\
\text { the identity of } \\
x^{\prime}\end{array}$ \\
\hline $\begin{array}{l}\text { (1) Inensive } \\
\text { ' } \boldsymbol{X} \text { is } \boldsymbol{a}^{\prime}\end{array}$ & Sara is wise & Sara is the leader \\
\hline $\begin{array}{l}\text { (2) Possessive } \\
\text { ' } \boldsymbol{x} \text { has } \boldsymbol{a} \text { ' }\end{array}$ & Peter has a piano & $\begin{array}{l}\text { The piano is } \\
\text { Peter's }\end{array}$ \\
\hline $\begin{array}{l}\text { (3) Circumstantial } \\
\text { 'x is at } \boldsymbol{a}^{\prime}\end{array}$ & $\begin{array}{l}\text { The fair is on } \\
\text { Tuesday }\end{array}$ & $\begin{array}{l}\text { Tomorrow is the } \\
10^{\text {th }}\end{array}$ \\
\hline
\end{tabular}

This table provides the following generalizations on relational clauses: 
(1) An attributive intensive clause has two participants: a Carrier and an Attribute. The Attribute is either an adjective or a common noun. This is illustrated in example 6:

6. [Carrier] Sarah [Pr: Intensive] is [Attribute] wise.

(2) In an identifying intensive clause, one entity, labelled Identifier, is used to identify another entity, labelled Identified.

7. [identified] These dinosaurs [Pr: Identifying] were [Identifier] the largest ever on earth.

$$
\text { (Halliday, 2014, p.276) }
$$

(3) In an attributive clause of possession, have is the unmarked verb. The participants are Carrier/Possessor and Attribute/Possessed.

8. [Carrier/Possessor] I [Pr: Possession] had [Attribute/Possessed] a daughter.

(4) However, in an identifying clause of possession, be is the unmarked verb. Thus example 9 can be interpreted as 'the piano is identified as something belonging to peter'.

9. [Carrier] The piano [pr: relational] is [Attribute/Possession] Peter's

(5) Relational circumstantial clauses describe the relationship between two components in terms of time, place, and manner. This relationship is illustrated in example 10.

10. [Carrier] The fair [Pr: relational] is [Attribute: Circumstantial] on Tuesday.

\subsubsection{Other process Types}

Halliday considers the material, the mental and the relational as the major process types in language as they can 
justify the majority of clauses in any text. However, he refers to other subsidiary process types that are crucial in attaining a thorough explanation of all aspects of a text. The remining processes to review are behavioural, verbal and existential.

Behaviourals are processes of physiological and psychological behaviour such as breathe, cough, smile, dream, stare, taste, and watch. Behaviourals often have one participant labelled Behaver. However, in a limited number of cases there can be a second participant called Behaviour if it is a restatement of the process (example 11.a), and Phenomenon if it is not a restatement of the process (example 11.b).

11.a. [Behaver] He [Pr: Behavioural] smiled [Behaviour] a broad smile.

11.b. [Behaver] She [Pr: Behavioural] sniffed [Phenomenon] the soup.

Verbal processes are identified in clauses of saying. Such processes are realized through verbal groups including verbs of saying like say, tell, speak, announce, notify, question, enquire etc. (Martin, Matthiessen \& Painter, 1997). A verbal process contains three participants: Sayer, Receiver, and Verbiage. The Sayer is identified as anything that gives a signal. This means that the act of saying has to be analyzed in a broader sense to include such participants as the underlined ones in example 12 below:

12.a. The notice tells you to keep quiet.

12.b. My watch says it is half-past-ten. 
12.c. The study says that such a diversified village structure produces a dualistic pattern of migration.

$$
\text { (Halliday, 2014, p.303-4) }
$$

The Receiver is the participant to whom the saying or the verbal process is directed. In example 12.a. above you is the Receiver. The Verbiage can simply be defined as "what is said'. In 12.a., the Verbiage is to keep quiet, and in 12.b. it is half-past-ten.

Existential clauses represent existence. They are headed by the empty particle there. The word there here cannot be considered a participant or a circumstance because it has no representational meaning in the transitivity system. Its function in a clause is simply to indicate existence (Halliday, 2014; Bloor \& Bloor, 1995). Existential processes are typically identified by the verb be and they have only one obligatory participant labelled Existent which refers to the event or entity that is "said to exist" (Halliday, 2014, p.309). For example, in the clause there was a stream, the Existent is a stream.

\subsubsection{Circumstances}

The last aspect of transitivity analysis to be considered, according to the Hallidayan model of transitivity is Circumstances. Halliday (2014) states that Circumstances can occur with all process types. They can be realized by adverbials or prepositional phrases. The major types of circumstantial elements are Extent (distance and duration), Location (place and time), manner (means, quality, comparison and degree), 
Cause (reason, purpose, and behalf) and Angle ( mostly linked to verbal processes).

\section{Transitivity Shifts in Translation}

It is observed that a source text undergoes changes or shifts on the level of transitivity when it is translated from one language into another (e.g. Perez, 2007, Catford, 1965). Vinay and Darbelnet (1958/ 1995) suggest a system of translation procedures that include three categories of translation shifts (though they did not use the term "shifts"): transposition (change in word category), modulation (change in meaning), and equivalence (providing a completely different translation). Catford (1965), who introduced the term "shifts" to translation studies, differentiates between formal correspondence and translational equivalence where the former occurs when the source and target categories occupy the same position in both the source text (ST) and the target text (TT), whereas the latter refers to two portions of texts that are actual translations of each other. A shift occurs when translational equivalents do not render formal correspondents.

The concept of translation shifts, adopted in this study, is based on Blum-Kulka (1986), van den Broeck (1986) and Perez (2007) according to whom shifts are TT deviations from the ST. Out of the two categories of shifts identified by van den Broeck (1986), shifts in stylistic and functional means and rhetorical structure shifts, this study focuses on the former category as it is the one which includes "characteristic choices 
of lexical units ...[and] syntactic structures" (p. 41) such as transitivity relations. Moreover, Blum-Kulka (1986, p.18) distinguishes between three types of structural shifts: shifts imposed by differences between ST and TT systems, shifts caused by stylistic preferences between ST and TT, and shifts resulting from the translation process itself. One more classification of structural shifts is Perez's (2007) transitivity shifts which include non-shifts (the translator manages to preserve the ST transitivity components including processes, participants, and circumstances), dematerialization (the translator's avoidance of ST material processes in the TT), and materialization ("ST non-material processes undergo materialization in the TT rendering”) (p. 161).

The transitivity shift model adopted in this study is shown in Figure 1, where transitivity shifts are regarded as shifts in stylistic and functional means. Transitivity shifts may be due to structural and stylistic differences between ST and TT, or the translation process itself. The translation process shifts are further subdivided into non-shifts, dematerialization shifts, and materialization shifts. 


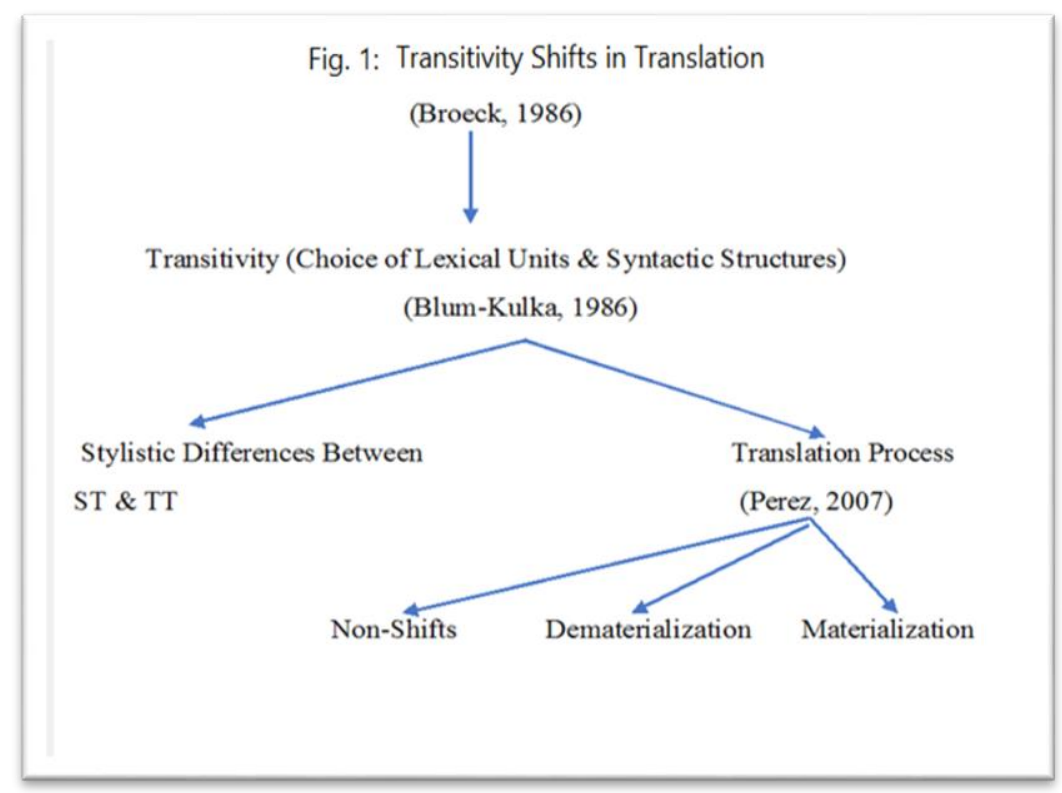

Figure1: Transitivity Shifts Model

\section{Research Questions}

1- What are the types of transitivity shifts that can be traced in the TT under investigation?

2- To what extent can transitivity shifts affect the transmission of meaning from the Arabic ST to the English TT?

\section{Data}

Mohamed Abed Al-jabri (1935-2010), a prominent intellectual figure in contemporary Arab thought, was a Professor of Philosophy and Islamic Thought in Moroccan universities. He was interested in the critique of the Arab mind and the urgent need for rereading Arabic and Islamic heritage in the light of the contemporary intellectual and technological 
development. His major intellectual project was to achieve a level of reconciliation or harmony between Islamic heritage and modernity as represented in the contemporary world scientific and intellectual advancement. In his book Democracy, Human Rights and Law in Islamic Thought (2009), Al-jabri traced such Western concepts as democracy, human rights, women's rights, and freedom of thinking in the light of the early Islamic tradition, particularly the Koran and prophetic tradition.

The translated text was originally two separate Arabic volumes that were published in 1996 and 2006 as Democracy and Human Rights [الديمقراطية وحقوق الإنسان] and Religion, State and the Application of Islamic LaW [الدين والدولة وتطبيق الشريعة] respectively. As late as 2009, the two volumes were compiled together and translated under the title: Democracy, Human Rights and Law in Islamic Thought. It is interesting to note that the translated book made no reference to the translator/translators, although it was published by a wellknown publisher, namely The Center for Arab Unity Studies, located in Beirut. Therefore, in this study, we consider the translator/s of the book as anonymous. This study focuses on analyzing randomly selected extracts from the original and the translated texts. In addition, for the purpose of analysis, the researcher relied on two monolingual dictionaries: the Arabic Alqamus AlMuheet by Majdu-eddin Alfayrouzabady, and the English Oxford Learner's Dictionary (OLD). 


\section{Analysis and results}

The extracts selected for analysis show that the data are abundant in the three types of shifts proposed by Perez (2007). In this section, the selected extracts are analyzed showing whether the shifts found are due to the obligatory differences between the two languages, or the nature of the translation process itself.

\subsection{Translation Process Shifts}

\subsubsection{Non-shifts}

Hardly can we say that the data contain many instances of non-shifts in the translation process. Example 13, however, is one of the very few examples where the translators managed to preserve the ST transitivity components in the TT.

13.

The danger of the spurious question is it demands an equally specious answer, which, in turn, raises further intractable problems. (p. 31)

وخطورة السؤال المزيف تكمن في انه يستدعي جوابا مزيفا يثير بدوره مشكلة أو مشاكل مزيفة . (p. 58) 


\begin{tabular}{|c|c|c|c|c|c|c|c|}
\hline $\begin{array}{l}\text { The } \\
\text { danger of } \\
\text { the } \\
\text { spurious } \\
\text { question }\end{array}$ & is & $\begin{array}{l}\text { it } \\
\text { demands } \\
\text { an } \\
\text { equally } \\
\text { specious } \\
\text { answer }\end{array}$ & which & $\begin{array}{l}\text { in } \\
\text { turn }\end{array}$ & raises & & $\begin{array}{l}\text { further } \\
\text { intractable } \\
\text { problems }\end{array}$ \\
\hline Identified & Pr:relational:identifying & Identifier & Senser & & Pr:mental & \multicolumn{2}{|c|}{ Phenomenon } \\
\hline Identified & Pr:relational:identifying & Identifier & Senser & & Pr:mental & \multicolumn{2}{|c|}{ Phenomenon } \\
\hline السؤال المزورة & تكمن في & جو ابا مزيفا & & بدوره & يثير & مشكلة & مشاكل مزيفة \\
\hline
\end{tabular}

The sentence in this example consists of two clauses, the first of which can be described as an identifying intensive relational clause. In this type of clause one entity, known as Identifier, is used to identify another entity, called Identified. So the clause can be understood as 'the demand for a specious answer identifies the danger of the spurious question'. The analysis of the example shows that all ST transitivity components are rendered without any kind of translation shift in TT. Still, the example also shows that the relational process (be) in English is the rendering of many Arabic forms as shown in the clauses in 14: 
14.

\begin{tabular}{|c|c|c|}
\hline 14.a & $\begin{array}{l}\text { The danger of the spurious } \\
\text { question is ... }\end{array}$ & المزيف تكمن في انه الهو \\
\hline 14.b & $\begin{array}{l}\text { The third possibility } \ldots \text { is } \\
\text { inconceivable... }\end{array}$ & أما الإحتمال الثالث \\
\hline 14.c & $\begin{array}{l}\text { Islam is a religion, not a } \\
\text { state }\end{array}$ & الإسلام دين لا دولة \\
\hline 14.d & $\begin{array}{l}\text { Islam is a religion and a } \\
\text { state }\end{array}$ & الإسلام دين ودولة \\
\hline
\end{tabular}

Example 14.a is the only clause which includes a ST process represented in the verbal group تكمن في [lit. lie in] which the translator renders as is. The possibility of structuring verbless clauses in Arabic leaves no choice before the translator but to add the relational process be when rendering such structures in English. So one of the important results yielded by the analysis is that the translator has to add some processes in order to preserve the grammaticality of the translated text.

As for the second clause of the sentence in example 13, / Which, in turn, raises further intractable problems, we are faced with a problem caused by the process يثير/raises. In the Arabic ST, this verb is simply recognized as cognitive, and the clause can be analyzed as senser pr:mental phenomenon. However, in English the same verb can be recognized as either material (Raise your hand before you speak), mental (His words raised suspicion), or behavioural ( $I$ had to raise my voice). The translator here uses 
it as a mental process to preserve the ST transitivity components.

(القاموس الخميط) أثار أثار الضَّحك : كان موضع سخرية ، -أثار انتباهه / أثار اهتمامه

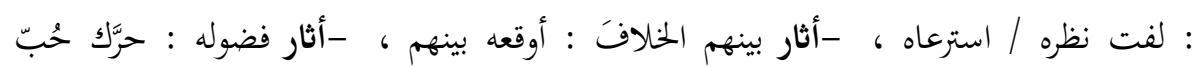

الاستطلاع لديه. (lit. raise)

\subsubsection{Dematerialization}

A common type of Translation shifts that is observed in the data is the translator's avoidance of material processes in the TT. This process is known as dematerialization and "involves the ST material processes being rendered in TT as ... nonmaterial processes" (Perez, 2007, p. 158).

15.

Nothing can obscure the vision like spurious questions which lead to emotional bewilderment and intellectual aberration. (p. 31)

\begin{tabular}{|c|c|c|c|c|c|c|c|c|}
\hline Nothing & can obscure & the vision & $\begin{array}{l}\text { like spurious } \\
\text { questions }\end{array}$ & which & lead to & $\begin{array}{l}\text { emotional } \\
\text { bewilderment }\end{array}$ & And & $\begin{array}{l}\text { intellectual } \\
\text { aberration }\end{array}$ \\
\hline senser & Pr: mental & $\begin{array}{l}\text { Phenomeno } \\
\mathrm{n}\end{array}$ & $\begin{array}{l}\text { Cir: manner: } \\
\text { comparison }\end{array}$ & behaver & Pr: behavioural & \multicolumn{3}{|l|}{ Behaviour } \\
\hline senser & Pr: mental & $\begin{array}{l}\text { Phenomeno } \\
\mathrm{n}\end{array}$ & $\begin{array}{l}\text { Cir: manner: } \\
\text { comparison }\end{array}$ & Actor & Pr: Material & \multicolumn{3}{|l|}{ Scope } \\
\hline لاشئ & يعتم & الرؤيا & كالأسئلة المزيفة & Ellipsis & ويوقع في & التيه الوجداني & و & الضلال الفكري \\
\hline
\end{tabular}

(Components that underwent shift in the translation are underlined)

As example 15 shows, this sentence contains two clauses. In the first clause, ( لا شيء يعتم الرؤيا / Nothing can obscure the 
vision), there is no shift of any kind in the translation as the Arabic mental process is translated as the English mental process obscure.

The second clause, however, demonstrates a clear process shift as the Arabic verbal group يوقع في [lit. drop in], which is identified as a material process, is rendered as lead to which is a behavioural process in English. The Arabic process يوقع is material as it includes doing or undertaking some action. However, its English rendering as the process "lead to" is behavioural in the sense that it is psychological behaviour which does include any doing or undertaking any action.

This process shift entails participant shift where the Arabic Scope (التيه الوجداني والضلال الفكري) is rendered as the English Behaviour "emotional bewilderment and intellectual aberration": the Arabic clause structure Actor Pr: Material Scope has become Behaver Pr:Behavioural Behaviour in English. It is also observed that the nominal participant, Actor, in the Arabic clause undergoes ellipsis to avoid repetition, but the translator finds it inevitable to add it in the form of the relative pronoun which because English does not allow a finite verb to occur without a preceding subject. Dictionary definitions of the processes show how this process shift influences the overall cognitive meaning of the whole clause.

$$
\text { وقَعَ يَقَعُ ، وُوقُوعاً : سَقَطَ ، (القاموس المحيط) يوقع في: }
$$

Lead to: to be an introduction to or the cause of something (OLD) 
The pattern of thinking associated with the process يوقع) (includes an action of sharp fall into a deep level, an action which may be severe or at least uncomfortable. However, the English process lead to is smooth and does not include any physical suffering.

\subsubsection{Materialization}

16.

In other words, transition to democracy may be achieved by one of two ways (p.146).

وبعبارة أخري: إن الإنتقال الى الديمقرطية يطرح من الناحية العملية أحد اختيارين.... (p)

\begin{tabular}{|c|c|c|c|c|}
\hline $\begin{array}{l}\text { In other } \\
\text { words }\end{array}$ & $\begin{array}{l}\text { transition to } \\
\text { democracy }\end{array}$ & may be achieved & & $\begin{array}{l}\text { by one of } \\
\text { two ways }\end{array}$ \\
\hline $\begin{array}{l}\text { Cir: } \\
\text { Angle }\end{array}$ & Goal & $\frac{\text { Pr: Material }}{\text { (Passive) }}$ & & Agent \\
\hline $\begin{array}{l}\text { Cir: } \\
\text { Angle }\end{array}$ & Sayer & Pr: Verbal & Cir: Manner & Verbiage \\
\hline وأخريبارة & إلى الإنتققر اطية & يطرح & من الناحية العملية & أحد اختيارين \\
\hline
\end{tabular}

The translation of the Arabic process (يطرح) undergoes two types of process shit: materialization in which "non-material processes undergo materialization" (Perez, 2007, p. 161), and passivization as the active process in the clause is rendered as passive. In Arabic, the process (يطرح) is categorized as Verbal in this context. A dictionary definition of the word in Arabic shows that it means "to pose a question, to present an issue for discussion and investigation”. 
In the English translation of the clause, the Verbal process is materialized and rendered as "achieve", the meaning of which includes the act of doing, or according to the OLD, of "making an effort". This results in a change in the meaning of the whole clause as posing the question of transition to democracy for discussion and investigation is different from achieving such a transition. Passivation and materialization together contribute to the translator's failure to render the intended meaning of the clause as the Sayer Participant in Arabic has become Goal, and the Arabic Verbiage is rendered in English as Agent.

$$
\begin{aligned}
& \text { طرّح عليه المسألةً : قدّمها ، عرضها للبحث والدّرس / (القاموس المخيط): طرَح المسألةً }
\end{aligned}
$$

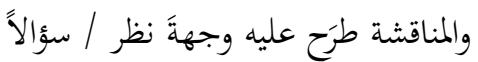

Achieve: achieve something to succeed in reaching a particular goal, status or standard, especially by making an effort for a long time.(OLD)

One more form of materialization which is imposed by stylistic and structural differences between Arabic and English occurs when the translator adds a material process to the TT where the ST includes no process. In example 17, the material process falls into is added to the TT clause to compensate for the absence of process in the ST.

17: The dichotomy of religion and state, in modern Arab thought, falls into this category of problem.

$$
\text { والثنائية التي نحن بصددها، ثنائية الدين والدولة، في الفكر العربي الحديث، هي من هذا }
$$




\begin{tabular}{|c|c|c|c|}
\hline $\begin{array}{l}\text { The dichotomy of } \\
\text { religion and state }\end{array}$ & $\begin{array}{l}\text { in modern } \\
\text { Arab thought }\end{array}$ & falls into & $\begin{array}{l}\text { this category of } \\
\text { problem. }\end{array}$ \\
\hline Actor & Cir: Time & Pr: material & Scope \\
\hline Identified & & $\begin{array}{l}\text { Pr: relational } \\
\text { identifying }\end{array}$ & Identifier \\
\hline بصددها بنائة الني نحن & في العربي الحديث & & النوي من هذا الأخير من \\
\hline
\end{tabular}

\subsubsection{Differences between $S T$ and TT}

Some translation shifts found in the data are due to stylistic differences between STs and TTs. This results in two phenomena referred to by Perez (2007) as expansion or "no process to process [and] contraction [or] process to no process" (p. 175]. Based on this, a single ST process can be expanded and rendered as multiple processes and multiple processes can be contracted as a single process.

A feature that has been traced in the ST is the use of coordination to connect two equivalent clause components. There is a number of coordinate conjunctions in Arabic

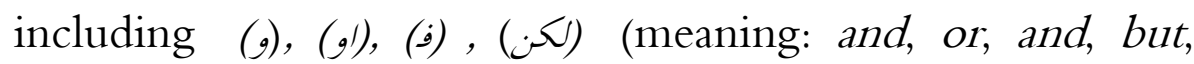
respectively). The ST includes many examples where the items connected are synonyms or near synonyms. The translator finds it inevitable to contract or reduce the number of the coordinated items to cope with the nature of the target language. In example18, the three ST processes (تنمو وتترسخ وتيمن) are contracted and rendered as two processes (grow and establish). 
18.

It gives the democratic powers in society a chance to grow and establish themselves (p. 175)

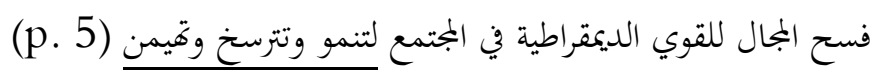

Contraction of processes in the TT takes different forms. In example 19, three finite processes in the ST (جعل, يسمى, تتحرر) are translated as only one process consisting of one finite group "helped" and one non-finite "to liberate". The verbal process did not occur in TT.

19.

$$
\begin{aligned}
& \text { قد جعل المسألة الديمقراطية في الوطن العربي وفي اقطار أخرى كثيرة مما كان يسمى بالعالم }
\end{aligned}
$$

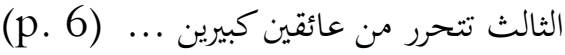

This helped the issue of democracy in the Arab nation and in many other so-called Third World countries to liberate themselves from two large obstacles ..... (P.149)

Contraction is not only represented in the dropping of some processes, but it is also depicted in that whole clauses in the ST are dropped in the translated TT and consequently the resulting sentence, which contain two clauses in the ST, is rendered as simple containing only one process/clause. In example 20, the Arabic sentence has two clauses where the bracketed one (في أقطار ينبي الحكم فيها على أسس غير ديعقراطية) is dropped in the translation.

20.

Moreover, the transition to democracy poses a practical problem... (p. 174) 


$$
\text { والإنتقال الى الديمقراطية (في أقطار ينبني الحكم فيها على أسس غير ديمقراطية) يطرح }
$$

The two Arabic processes يطرح / ينبني are merged together and translated as one process "Poses".

Furthermore, the data provides examples of process expansion, where the translator finds it inevitable to expand the number of processes in his/her rendering. The ST in example 21 consists of only one clause represented in the material passivized process (يوضع), whereas the TT contains four processes, two material processes (directs and is placed), and the relational process (is), which is used twice in the clause. It is generally observed that the process which is frequently used in expansion is the relational be as shown in examples 21.

21.

$$
\text { والمبدأ المؤسس لهذه المرجعية والمتحكم في توجيهها هو ان كل ما يوضع في مقابل الإسلام }
$$

The foundation principle of this referential authority, which directs all its movements, is that whatever is placed in apposition to Islam is alien to Islam.

\section{Concluding Remarks}

This study investigates the extent to which transitivity relations in the ST are affected by the nature of the TT language when the ST is translated. From the analysis above, it can be seen that stylistic and syntactic differences between Arabic and English make it inevitable for the translators of al- 
Jabry's text to change some transitivity relations when they render it from Arabic into English.

The results show that material processes are dominant in both ST and TT. However, it has been observed that the relational processes, based on being and having, are more frequent in the TT than in the ST. This may be due to the fact that the relational process be is often implicit in Arabic, and when a relational clause is translated from Arabic into English, the translator has no choice but to add a relational process to the translated clause. The analysis gives evidence that the English relational process $b e$ is the rendering of various Arabic structures as shown in the examples below:

\begin{tabular}{|c|c|}
\hline $\begin{array}{l}\text { Therefore, the initial question is } \\
\text {.. }\end{array}$ & للقنا منه .. \\
\hline $\begin{array}{l}\text { You may do your best to convince } \\
\text { them that it is neither this nor that }\end{array}$ & 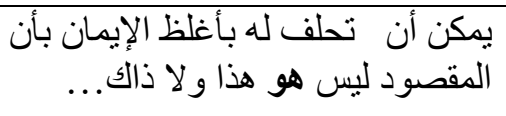 \\
\hline $\begin{array}{l}\text { This is because religion in the } \\
\text { eyes of such a person ... }\end{array}$ & في نظره... \\
\hline $\begin{array}{l}\text { while religion must be above all } \\
\text { this ... }\end{array}$ & أما إ \\
\hline
\end{tabular}

The results also yield a significant process shift which is represented in materialization and dematerialization where non-material processes are rendered material and vice versa. The most frequent types of materialization are represented in relational and verbal Arabic clauses being translated into English as material. This type of shift results in deviations from the meaning intended by the ST author. 


\begin{tabular}{|c|c|c|}
\hline a. relational & to & material (causative) \\
\hline 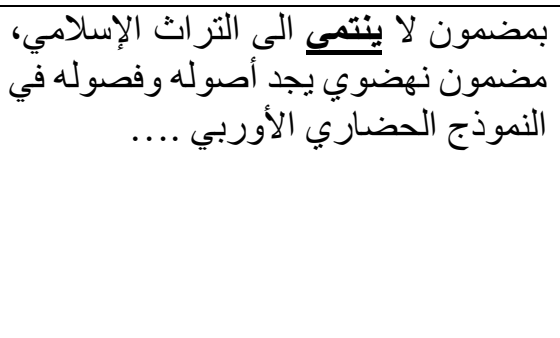 & & $\begin{array}{l}\text { It was brought forth in the } \\
\text { context of [the Arab } \\
\text { revival], foreign to Islamic } \\
\text { thought, with roots and } \\
\text { terminology found in the } \\
\text { European civilizational } \\
\text { model .... }\end{array}$ \\
\hline $\begin{array}{l}\text { b. implicit relational } \\
\text { identifying }\end{array}$ & to & material \\
\hline المشاكلية هي من هذا النوع الأخير من & & $\begin{array}{l}\text { The dichotomy falls into } \\
\text { this category of problem... }\end{array}$ \\
\hline c. Verbal & to & material \\
\hline الإنتقال ألى الختيمقر اطية يطرح من الناحية & & $\begin{array}{l}\text { transition to democracy } \\
\text { may be achieved by one of } \\
\text { two ways }\end{array}$ \\
\hline d. material & to & behavioural \\
\hline الفكريو في التيه الوجداني والضلال & & $\begin{array}{lr}\text { lead to } & \text { emotional } \\
\text { bewilderment } & \text { and } \\
\text { intellectual aberration } & \end{array}$ \\
\hline
\end{tabular}

Finally, contraction and expansion of processes are two types of translation shifts which are imposed by stylistic differences between ST and TT. Coordinated synonymous or near synonymous processes in Arabic are contracted or reduced in English to avoid repetition. However, there are other positions where translators add/expand processes in order to produce structurally well-formed TT sentences. 


\section{References}

Al-Jabry, M. A. (2009). Democracy, Human Rights and Law in Islamic Thought. Beirut: Center for Arab Unity Studies.

Al-Jabry, M. A. (2006). Democracy and Human Rights [الديمقراطية وحقوق الإنسان]. UNESCO

Al-Jabry, M. A. (1996). Religion, State and the Application of Islamic Law [الدين والدولة وتطبيق الشريعة]. Beirut: Center for Arab Unity Studies.

Bell, R. T. (1991, 1993). Translation and Translating: Theory and Practice. Longman: London and New York.

Bloor, T. and Bloor, M. (1995). The functional analysis of English; a Hallidayan approach.

New York: Arnold.

Blum-Kulka, S . (1986). Shifts of cohesion and coherence in translation. In Juliane House \& Shoshana Blum-Kulka (eds.), Interlingual and intercultural communication. Tübingen: Gunter Narr. Pp. , 17-35.

Bosseaux, C. (2007). How Does it Feel? Point of View in Translation: The Case of Virginia Woolf into French. Amsterdam - New York: Editions Rodopi B.V.

Catford, J G (1965). A Linguistic Theory of Translation: An Essay in Applied Linguistics. Oxford University Press, Oxford.

Eggins, S. (2004). An Introduction to Systemic Functional Linguistics. (2 ${ }^{\text {nd }}$ Edition). New York. London: Continuum. 
Foran, L. (2012). What is the Relation between Translation and Philosophy? In Lisa Foran (Ed.) Intercultural Studies and Foreign Language Learning. Volume II Translation \& Philosophy, P. 3.

Halliday, M. A. K. (1967). Notes on Transitivity and Theme in English: Part 1. Journal of Linguistics, 3, No.1, PP. 37-81.

Halliday, M. A. K. (2014). Halliday's Introduction to Functional Grammar. ${ }^{\text {th }}$ Edition. New York: Rutledge.

Halliday, M.A. K. (1994). An Introduction to Functional Grammar. Edward Arnold Ltd.

Harden, T. (2012) The Awful German Language, or, Is 'Die Geistige Entwicklung' 'The Mental Development'? In Lisa Foran (Ed.) Intercultural Studies and Foreign Language Learning.VolumeII Translation \& Philosophy, Pp. 13-26.

Hatim, B. \& Munday, J. (2004). Translation: An Advanced Resource Book. Routledge: London and New York.

Ingarden, R. (1991). On Translation. In A-T. Tymieniecka (Ed.), Analecta Husserliana, Vol.XXXIII. pp. $131-192$

Jakobson, R. (1959). 'On Linguistic Aspects of Translation', in R. A. Brower (ed.) On Translation. Cambridge, MA: Harvard University Press, pp. 232-39. 
Martin, R. J., Matthiessen, M. I. and Painter, C. (1997). Working with functional grammar. London: Arnold.

Matthiessen, M. , Teruya, K. and Lam, M. (2010). Key Terms in Systemic Functional Linguistics. London \& New York: Continuum.

Perez. M. C. (2007). Transitivity in Translating, the Interdependence of Texture and Context. Bern: Peter Lang AG.

Simpson, P. (1993). Language, Ideology and Point of View. New York: Routledge.

van den Broeck, R. (1986). Contrastive discourse analysis as a tool for the interpretation of shifts in translated texts. In Juliane House \& Shoshana Blum-Kulka (eds.), Interlingual and intercultural communication. Tübingen: Gunter Narr. Pp. 37-47.

Van-leuven-Zwart, M. (1990) Translation and original: Similarities and dissimilarities, II. Target, 2(1):69-95.

Vinay, J. P. \& J. Darbelnet (1958/1995). trans. and ed. J. C. Sager and M.-J. Hamel (1995) as Comparative Stylistics of French and English: A Methodology for Translation. Amsterdam and Philadelphia: John Benjamins. 